\title{
Exploring Korean Collegians' Social Commerce Usage: Extending Technology Acceptance Model with Word-of-Mouth and Perceived Enjoyment
}

\author{
Jihyuk Joo \\ Depart. of Journalism \& Communication, Far East University \\ School of Communication, Northen Arizona University \\ 우리나라 대학생의 소셜커머스 이용에 대한 탐색: \\ 구전효과와 인지적 즐거움으로 확장한 기술수용모형의 적용 \\ 주지혁 \\ 극동대학교 언론홍보학과 \\ 노던아리조나대학교 커뮤니케이션학부
}

\begin{abstract}
Social commerce is a combination of social media and shopping. Social commerce, based on Web 2.0 technologies, has the various potentials, which is the factor attracting customers. In Korea, collegians are more active user of social media, in turn, are estimated more active customer in social commerce context. Present research explored what made Korean collegians use social commerce with extending technology acceptance model(TAM) with word-of-mouth(WOM) and perceived enjoyment(PE). We found that WOM affected indirectly the intention to use(ITU) with mediating PE, in turn, PE has a positive effect on the all of constructs in TAM. Accordingly, TAM extended with WOM and PE is validated in social commerce context. Finally, based on the findings, implications and suggestions for future studies are discussed.
\end{abstract}

Key Words : Social Commmerce, Technology Acceptance Model, Word-of-Mouth, Perceived Enjoyment

요 약 소셜커머스는 소셜미디어와 쇼핑의 결합이다. 웹 2.0 기술에 기반을 둔 소셜커머스는 다양한 잠재력을 가지 고 있고, 이러한 잠재력을 통해 소비자를 유인하고 있다. 한국의 대학생들은 소셜미디어 사용에 매우 적극적인데, 소 셜커머스 사용에 있어서도 매우 적극적 소비자로 추정된다. 이러한 관점에서 본 연구는 한국 대학생들이 소셜커머스 를 이용하게 하는 것이 무엇인지를 밝히기 위해 구전효과(Word-of-Mouth)과 인지적 즐거움(Percieved Enjoyment)으로 확장한 기술수용모형을 검정했다. 연구결과, 구전효과는 인지적 즐거움을 매개하여 소셜커머스 이용의도에 영향을 미 치고 있었다. 인지적 즐거움은 기술수용모형의 모든 구성개념들에 긍정적 영향을 미치고 있다. 따라서 구전효과와 인 지적 즐거움으로 확장한 기술수용모형은 한국의 소셜커머스 맥락에서 유효함이 입증되었다. 마지막으로 향후 연구를 위한 함의와 제안을 제시했다.

주제어 : 소셜커머스, 기술수용모형, 구전효과, 인지적 즐거움

Received 12 June 2014, Revised 15 July 2014

Accepted 20 August 2014

Corresponding Author: Jihyuk Joo(Far East University)

Email: hyukjoo@kdu.ac.kr

ISSN: $1738-1916$
(C) The Society of Digital Policy \& Management. All rights reserved. This is an open-access article distributed under the terms of the Creative Commons Attribution Non-Commercial License (http://creativecommons.org/licenses/by-nc/3.0), which permits unrestricted non-commercial use, distribution, and reproduction in any medium, provided the original work is properly cited. 


\section{Introduction}

Social commerce means social media meets shopping[1]. As known, social media is based on Web 2.0 that uses technologies beyond the static pages of earlier web sites. Web 2.0 features more interactive and collaborative internet that emphasize the social interaction and collective intelligence[2]. The Web 2.0 combines $\mathrm{e}^{-}$-commerce to result in social commerce. Generally, most Koreans tend to regard social commerce as group buying or social shopping[3] because most social commerce firms are based on social networking service(SNS) as platform. Accordingly, social commerce aims for more customer satisfaction, user participation and social interaction based on crowd-sourcing, consumer-generated content or live shopping[4].

Collegians are reported most using social media in Korea. According to Korea Communications Commission (KCC) and National Internet Development Agency of Korea (NIDA)[5], 76.8\% of collegians (including graduate school) are SNS users, as collegians are most outstanding user of social media in Korea. Thus, collegians could be estimated more active and heavier social commerce user.

Present research explores what makes Korean collegians use the social commerce extending technology acceptance model (hereafter "TAM") with word-of-mouth (hereafter "WOM") and perceived enjoyment(hereafter "PE"). Theoretically, this research aim to suggest extended TAM for a more powerful and robust model. Practically, spreading social commerce, collegians, outstanding users of social media, are analyzed regarding their social commerce behaviors. They are, actually, a powerful potential customer with purchasing power in online market. They are familiar with SNS and social commerce prepares diverse assortment of products for them. Thus, understanding their social commerce behavior gives the practitioners implications for future business.

\section{Literature Review and Hypotheses}

\subsection{Word of Mouth}

According to Kim and Prabhakar[6], information about an innovation (e.g., social commerce) "is communicated through certain channels over time among the members of a social system"[7](p. 5). In social network theory[8], informal channels (e.g., WOM) of communication plays a primary role in disseminating information to a market when the services are particularly complex and difficult to evaluate[6,9]. The service quality of social commerce is difficult to evaluate without firsthand experience. The consumer's uncertain perceptions about social commerce should be influenced by WOM referrals.

WOM is defined as the informal communication directed at other consumers about ownership, or characteristics of particular goods and services and/or their sellers[10]. WOM is a powerful tool at marketing practice due to following[11]: First, WOM is more credible than commercial sources of information controlled by companies (e.g. advertising, sponsorship). Most of our discussions are indeed with friends, family, i.e. people we trust and whose goal is not the promotion of a specific company. Second, WOM is really communication, i.e. the message flow tends to be two-way. Third, WOM provides potential consumers with a description of what the experience would be and is thus considered to be a risk reliever, especially for experience goods. According to Buttle[12], "positive WOM occurs when good news testimonials and endorsements desired by the company are uttered, whereas negative WOM is the mirror image"(p. 4).

In previous studies, WOM plays a predictive role in a lot of transaction researches. Analyzing intention to use e-learning with TAM extended with WOM, Lee[13] reports WOM has a positive effect on PE. Furthermore, Han, Kim, and Lee[14] confirms that WOM has a positive influence on intention to purchase at social commerce. Based on these works, present 
study sets forth the following hypothesis:

H1. WOM will have a positive effect on PE.

H2. WOM will have a positive effect on intention to use (hereafter "ITU”).

\subsection{Perceived Enjoyment}

The shopping is a hedonic activity to pursue self-satisfaction. Customers on social commerce act voluntarily and hedonically. They participate in it because they are intrinsically motivated[15]. Accordingly, PE is a key concept to understanding customer's electronic transaction behavior.

The studies of technology adoption define PE as the extent to which the activity of using a specific system is perceived to be enjoyable in its own right, aside from any performance consequences resulting from system use[16].

In previous studies, $\mathrm{PE}$ affects positively technology acceptance model (hereafter "TAM") constructs: perceived ease of use (hereafter "PEOU") and perceived usefulness (hereafter "PU")[17], and intention to use technologies[15, 18, 19]. Based on these findings, we hypothesize that:

H3. PE will have a positive effect on PEOU.

H4. PE will have a positive effect on PU.

H5. PE will have a positive effect on ITU.

\subsection{Technology Acceptance Model}

TAM is a prominent theoretical framework employing for identifying adoption of new technology. TAM is based on two salient behavioral beliefs that affect behavioral intentions: PEOU and PU. Davis[20] defines PEOU as "the degree to which a person believes that using a particular system would be free of effort" and PU as "the degree to which a person believes that using a particular system would enhance his or her job performance"(p. 320).
TAM is valued as a powerful and robust model to explain and predict acceptance of a new technology, whereas TAM has two limitations: First, since the original model aims to be general and parsimonious, it pays little attention to identifying the antecedent of the two salient behavioral belief, PEOU and PU [21, 22]. Futhermore, even though the model is good at identifying factors that influence people's technology acceptance and use, the model cannot fully explain why people accept and use a particular technology[22, 23]. For overcoming these limitations of TAM, this study aims to extend TAM with WOM and PE.

Since Davis[20], the studies employing TAM have made sure that PEOU affects PU and ITU, in turn, PU affects ITU. Accordingly, present study sets forth the following hypothesis:

H6. PEOU will have a positive effect on PU.

H7. PEOU will have a positive effect on ITU.

H8 PU will have a positive effect on ITU.

Based on the above hypotheses, we illustrate the research model in [Fig. 1].

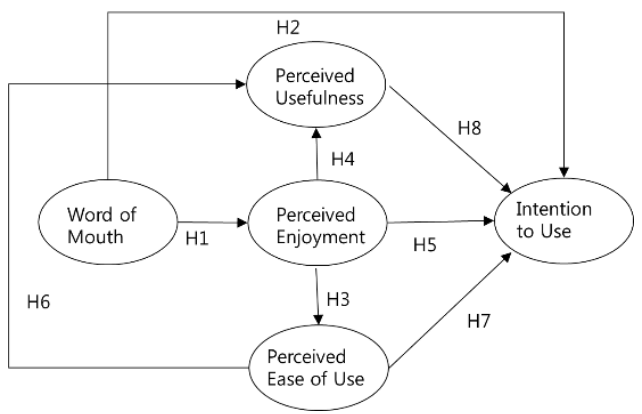

[Fig. 1] Proposed research model

\section{Method}

\subsection{Sample}

The participants chosen for the present study were 565 Korean collegians who had connected to and 
purchased from social commerce services through a convenience sampling method. The demographic profiles are presented in $\langle$ Table 1$\rangle$.

As Table 1 shows, $49.56 \%$ of the respondents were male with $50.44 \%$ female. In terms of education, $29.03 \%$ of the respondents were freshman; $28.85 \%$ were junior; $26.85 \%$ were sophomore; and $15.4 \%$ were senior. Moreover, as for age, the mean is 22.10 with standard deviation 1.93. The oldest 2 person are 28 years old, whereas the youngest 139 person are 20 years old.

\section{〈Table 1〉 Demographic Profile}

\begin{tabular}{c|c|c}
\hline Demographic & $\mathrm{N}$ & Percentage \\
\hline male & 280 & 49.56 \\
female & 285 & 50.44 \\
\hline freshman & 164 & 29.03 \\
sophomore & 151 & 26.73 \\
junior & 163 & 28.85 \\
senior & 87 & 15.4 \\
\hline
\end{tabular}

\subsection{Survey Administration and Measurement}

To test the hypotheses, the present study employed a self-reported survey of Korean collegians who had connected to and purchased from social commerce services. Trained interviewers with a major in communication administered the questionnaires. The survey was administered for two weeks from May 27 to June 10, 2013.

This study tests the effects of WOM, PE, PEOU and PU on intention to use social commerce. The measurement instruments consist of a six-part questionnaire that was modified from previous studies: demographic, WOM, PE, PEOU, PU, and ITU. The Appendix shows the scales used to measure these items.

\subsection{Data Analysis}

This study employed PLS path modeling to test structural causalities among the five underlying constructs: WOM, PE, PEOU, PU and ITU. According to Gefen and Straub[24], "PLS merges a factor analysis with multiple linear regressions to estimate the parameters of the measurement model (item loadings on constructs) together with those of the structural model (regression paths among the constructs) by minimizing residual variance (p. 414).” PLS enables researchers to examine the validity of the discriminant and convergent scales, which is a requisite for examining a new model.

The present study employs the PLS method because it has more advantages than the covariance-based structural equation modeling (SEM) approach such as LISREL and AMOS[25, 26]. Whereas the sample size is emphasized in the SEM approach, PLS is free from it and is appropriate for small sample size research[25-27]. Gefen et al.[27] and Chin[28] suggested that the minimum sample size in PLS path modeling should be 10 times the number of items related to the most complex variable or constructs. Moreover, PLS is a proper method for exploratory research[24-26, 28] due to the availability of PLS to test the new model and theory[27]. Accordingly, social commerce is the latest issue and lacks a robust theory base, so the present study employs the PLS method using the SmartPLS 2.0 M3 package.

\section{Findings}

\subsection{Reliability and Validity of Measurement Scale}

To examine the reliability and validity of measurement scales, the present study executes PLS Algorithm on Calculate tap of SmartPLS package[29] to get Cronbach's Alpha(a) and composite reliability

Table 2 shows the overview of PLS quality criteria. In Table 2 , composite reliability is greater than the minimum criterion, 0.7 ; consequently, the reliability of measurement scales is appropriate for analysis. Furthermore the Cronbach's a of constructs are greater than 0.6, the minimum criterion, and indicates reliable values. 
〈Table 2〉 PLS Quality Criteria Overview

\begin{tabular}{c|c|c|c|c}
\hline & AVE & $\begin{array}{c}\text { Composite } \\
\text { Reliability }\end{array}$ & $\begin{array}{c}\text { R } \\
\text { Square }\end{array}$ & $\begin{array}{c}\text { Cronbach's } \\
\text { Alpha }\end{array}$ \\
\hline ITU & 0.799 & 0.923 & 0.575 & 0.874 \\
\hline PEOU & 0.762 & 0.906 & 0.214 & 0.844 \\
\hline PE & 0.659 & 0.852 & 0.109 & 0.743 \\
\hline PU & 0.665 & 0.908 & 0.398 & 0.874 \\
\hline WOM & 0.745 & 0.898 & & 0.830 \\
\hline
\end{tabular}

To examine construct validity of the measurement model, this research employs convergent and discriminant validity[30]. To examine convergent validity, present research considers AVE (Average Variance Extracted), of which greater than 0.50 is valid convergent validity [24, 31]. In $\langle$ Table 2$\rangle$, AVE in all constructs is over 0.5. Accordingly, we accept that current research achieves the criterion.

To test discriminant validity, we compare the inter-correlations within latent constructs with the root square of AVE of latent constructs. According to Gefen and Straub[32], if the square root of AVE of each construct is greater than its correlations with the other latent constructs, the discriminant validity is significant. $<$ Table $3>$ indicates that the square root of AVE of construct is appropriate to the criterion respectively.

〈Table 3〉 Latent Construct Correlation

\begin{tabular}{c|c|c|c|c|c}
\hline & ITU & PEOU & PE & PU & WOM \\
\hline ITU & 0.894 & & & & \\
\hline PEOU & 0.457 & 0.873 & & & \\
\hline PE & 0.616 & 0.463 & 0.812 & & \\
\hline PU & 0.703 & 0.479 & 0.586 & 0.816 & \\
\hline WOM & 0.471 & 0.377 & 0.330 & 0.504 & 0.863 \\
\hline
\end{tabular}

Parentheses show square root of AVE

\subsection{Test of Structural Model}

$<$ Table $4>$ indicates the findings of hypotheses test and path coefficients of the proposed research model. In PLS path modeling, the model validity is appraised by the $\mathrm{R}$ square value and the structural paths[33]. This research executed bootstrapping to estimate the statistical significance of the construct's path coefficient by means of $\mathrm{t}$-tests.

In the research model, WOM path coefficient of its causal links with ITU is not significant. PEOU-ITU path coefficient is not significant as well. It means WOM and PEOU are not influencing intent to use social commerce in the model.

However, all of the other path coefficients are significant and the findings support their hypotheses. In detail, WOM predicted PE positively $(\beta=0.33$, $\mathrm{t}=2.83$, $\mathrm{p}<0.005$, one-tailed test). PE predicted PEOU $(\beta=0.46$, $\mathrm{t}=5.31, \mathrm{p}<0.0005$, one-tailed test), $\mathrm{PU}(\beta=0.46, \mathrm{t}=4.72$, $\mathrm{p}<0.0005$, one-tailed test) and ITU $(\beta=0.29, \mathrm{t}=2.84$, $\mathrm{p}<0.005$, one-tailed test) positively. PEOU predicted PU ( $\beta=0.27, t=2.22, p<0.05$, one-tailed test) positively. $P U$ also predicted ITU $(\beta=0.44, t=3.98, p<0.0005$, one-tailed test) positively. It appears in Table 4 with the $\mathrm{t}$-values.

In $\langle$ Table 2$\rangle$, the $\mathrm{R}$ squares have been shown and indicate that $57.5 \%$ of the variance in ITU was accounted for by the constructs in this model. This means PU affect ITU directly, and PE affect ITU directly and indirectly. WOM and PEOU affect ITU

〈Table 4〉 Hypotheses Test Results

\begin{tabular}{|c|c|c|c|c|c|c|c|c|}
\hline & & $\begin{array}{l}\text { Original } \\
\text { Sample } \\
(0)\end{array}$ & $\begin{array}{l}\text { Sample } \\
\text { Mean } \\
(\mathrm{M})\end{array}$ & $\begin{array}{l}\text { Standard } \\
\text { Deviation } \\
\text { (STDEV) }\end{array}$ & $\begin{array}{l}\text { Standard } \\
\text { Error } \\
\text { (STERR) }\end{array}$ & $\begin{array}{l}\text { T Statistics } \\
(|\mathrm{O} / \mathrm{STERR}|)\end{array}$ & $\mathrm{p}$ & Result \\
\hline H1 & $\mathrm{WOM} \rightarrow \mathrm{PE}$ & 0.330 & 0.332 & 0.117 & 0.117 & 2.832 & $\mathrm{p}<0.005$ & $\begin{array}{c}\text { supported } \\
\text { (one-tailed test) }\end{array}$ \\
\hline $\mathrm{H} 2$ & $\mathrm{WOM} \rightarrow \mathrm{ITU}$ & 0.131 & 0.134 & 0.094 & 0.094 & 1.395 & - & unsupported \\
\hline H3 & $\mathrm{PE} \rightarrow \mathrm{PEOU}$ & 0.463 & 0.467 & 0.087 & 0.087 & 5.312 & $\mathrm{p}<0.0005$ & $\begin{array}{c}\text { Supported } \\
\text { (one-tailed test) }\end{array}$ \\
\hline H4 & $\mathrm{PE} \rightarrow \mathrm{PU}$ & 0.463 & 0.470 & 0.098 & 0.098 & 4.727 & $\mathrm{t}<0.005$ & $\begin{array}{c}\text { Supported } \\
\text { (one-tailed test) }\end{array}$ \\
\hline H5 & $\mathrm{PE} \rightarrow \mathrm{ITU}$ & 0.286 & 0.291 & 0.101 & 0.101 & 2.838 & $\mathrm{p}<0.005$ & $\begin{array}{c}\text { Supported } \\
\text { (one-tailed test) }\end{array}$ \\
\hline $\mathrm{H} 6$ & $\mathrm{PEOU} \rightarrow \mathrm{PU}$ & 0.265 & 0.259 & 0.119 & 0.119 & 2.223 & $\mathrm{p}<0.025$ & $\begin{array}{c}\text { Supported } \\
\text { (one-tailed test) }\end{array}$ \\
\hline $\mathrm{H} 7$ & $\mathrm{PEOU} \rightarrow \mathrm{ITU}$ & 0.065 & 0.067 & 0.101 & 0.101 & 0.641 & - & unsupported \\
\hline H8 & $\mathrm{PU} \rightarrow \mathrm{ITU}$ & 0.438 & 0.430 & 0.112 & 0.112 & 3.918 & $\mathrm{p}<0.005$ & $\begin{array}{c}\text { Supported } \\
\text { (one-tailed test) }\end{array}$ \\
\hline
\end{tabular}


indirectly, mediated by $\mathrm{PE}$ and $\mathrm{PU}$ respectively. PE, resulting in the $\mathrm{R}^{2}$ of 0.11 , is affected by WOM; PEOU, resulting in the $\mathrm{R}^{2}$ of 0.214 , is affected by $\mathrm{PE}$; $\mathrm{PU}$, resulting in the $\mathrm{R}^{2}$ of 0.40 , is affected by $\mathrm{PE}$ and PEOU. Respectively 11\%, 21\% and 40\% of PE, PEOU and PU variance are accounted for by the antecedent variables.

\section{Conclusion and Discussion}

This study tries to explain the Korean collegians' use of social commerce through extending TAM with WOM and PE. We proposed and examined hypothesized paths in the research model. To analyze the causalities among underlying constructs, present study employs PLS path modeling method.

In sum up, WOM-ITU and PEOU-ITU path are not significant, whereas all of the other paths support hypotheses proposed in the research model. The findings mean the model, extended TAM with WOM and $\mathrm{PE}$, is valid in terms of explaining Korean collegians' social commerce usage.

According to existing empirical evidence, PE has stronger impacts on ITU for hedonic systems than utilitarian[34, 35]. Moreover, PE-PEOU path is significant in utilitarian systems[17, 36-39]. We find that PE does not affect ITU and PE-PEOU path is valid. The findings mean Korean collegians perceive social commerce utilitarian system. Accordingly, the industrial practitioners should approach the younger customers in terms of the implication. Furthermore, WOM referral has indirect effect on ITU. The finding results from the fact that Korean collegian customers regard social commerce as group buying and social shopping based on SNS. This is understood in terms of initiative role of SNS on social commerce. Due to emphasizing 'fun and humor marketing strategies,' administered on SNS for attracting customer's attention, WOM is not a direct irritant to ITU but an indirect, mediated by PE. Thus, the practitioner should consider the substance of social commerce, so-called combination of social media and shopping, and emphasize more social media's potentials (e.g. openness, participation, connectedness, interaction, and share) to affect ITU directly than fun and humor.

Finally, the following is some suggestions for future researches. According to the finding, social commerce has characteristics of a utilitarian system. So, the user's intrinsic motives should be extended with TAM(e.g. extending TAM with uses and gratifications approach [22]). Moreover, in terms of the functional alternative, we need to understand the characteristics social commerce as functional alternative to existing transactional behaviors. Through the works, the industrial practitioners should be expected to get practical implications.

\section{REFERENCES}

[1] L. Indvik. "The 7 species of social commerce," Nov. 4, 2013;

http://mashable.com/2013/05/10/social-commerce-d efinition/.

[2] S. Murugesan, "Understanding web 2.0," IT Pro, pp. 34-41, July/August, 2007.

[3] J. You, "'Social commerce' makes consumer business' companion," LG Business Insight, pp. 31-37, Feburary 16, 2011.

[4] P. Leitner, and T. Grechening, "Collaborative shopping networks: Sharing the wisdom of crowds in e-commerce environments," in 21st Bled eConfernece eCollaboration: Overcoming Boundaries through Multi-Channel Interaction, Bled, Slovenia, 2008.

[5] KCC, and NIDA, "Survey on the SNS Usage," June, 2009.

[6] K. Kim, and B. Prabhakar, "Initial trust, perceived risk, and the adoption of internet banking," in Proceedings of the twenty first international conference on Information systems, 2000, pp. 
537-543.

[7] E. Rogers, Diffusion of Innovation, 3rd ed., New York: The Free Press, 1983.

[8] M. Granovetter, "The strength of weak ties," American Journal of Sociology, vol. 78, pp. 1360-1380, 1973.

[9] J. Brown, and P. Reingen, "social ties and word-of mouth referral behavior," Journal of Consumer Research, vol. 14, pp. 350-362, 1987.

[10] R. A. Westbrook, "Product/consumption-based affective responses and postpurchase process," Journal of Marketing Research, vol. 24, no. 3, pp. 258-270, 1987.

[11] C. Derbaix, and J. Vanhamme, "Inducing word-of-mouth by eliciting surprise-a pilot investigation," Journal of Economic Psychology, vol. 24, no. 1, pp. 99-116, 2003.

[12] F. A. Buttle, "I heard it through the grapevine: Issues in referral marketing," in 5th International Colloquium in Relationship Marketing, Carnfield School of Marketing, Cranfield University, England, 1997.

[13] J.-M. Lee, "Role of perceived enjoyment and perceived usefulness in intention to use e-learning: Differences of use experience degree and age," Korea Journal of Business Administration, vol. 25, no. 1, pp. 211-225, 2012.

[14] S. Han, Y. Kim, and B. G. Lee, "The effects of characteristics of social commerce on purchase intention: Focusing on the moderating effect of social network service," Journal of Internet Computing and Services, vol. 12, no. 6, pp. 171-187, 2011.

[15] J. Shen, "Social comparison, social presence, and enjoyment in the acceptance of social shopping websites," Journal of Electronic Commerce Research, vol. 13, no. 3, pp. 198-212, 2012.

[16] F. D. Davis, R. P. Bagozzi, and P. R. Warshaw, "Extrinsic and intrinsic motivation to use computers in the workplace," Journal of Applied Social Psychology, vol. 22, no. 14, pp. 1111-1132, 1992.
[17] M. Y. Yi, and Y. Hwang, "Predicting the use of web-based information systems: Self-efficacy, enjoyment, learning goal orientation, and the technology acceptance model," International Journal of Human-Computer Studies, vol. 59, no. 4, pp. 431-449, 2003.

[18] Y.-J. Mun, and J.-H. Lee, "A study on the effect of social presence, playfulness, satisfaction, trust formation on repurchase intention in $\mathrm{B} 2 \mathrm{C}$ electronic commerce: focused on the open market users," The e-Business Studies, vol. 10, no. 1, pp. 63-87, 2009.

[19] T. Ramayah, and J. Ignatius, "Impact of perceived usefulness, perceived ease of use and perceived enjoyment on intention to shop online," ICFAI Journal of Systems Management (IJSM), vol. 3, no. 3, pp. 36-51, 2005.

[20] F. D. Davis, "Perceived usefulness, perceived ease of use, and user acceptance of information technology," MIS Quarterly, vol. 13, no. 3, pp. 319-340, 1989.

[21] M. T. Dishaw, and D. M. Strong, "Extending the technology acceptance model with task-technology fit constructs," Information \& Management, vol. 36, no. 1, pp. 9-21, 1999.

[22] J. Joo, and Y. Sang, "Exploring Koreans' smartphone usage: An integrated model of the technology acceptance model and uses and gratifications theory " Computers in Human Behavior, vol. 29, no. 6, pp. 2512-2518, 2013.

[23] N. Park, "Adoption and use of computer-based voice over internet protocol phone service: Toward an integrated model," Journal of communication, vol. 60, no. 1, pp. 40-72, 2010.

[24] D. Gefen, and D. W. Straub, "Consumer trust in B2C e-Commerce and the importance of social presence: experiments in $\mathrm{e}$-Products and e-Services," Omega The International Jorunal of Management Science, vol. 32, pp. 407-424, 2004.

[25] M. Hajli, "Social commerce adoption model," in UK Academy of Information Systems Conference, 2012. [26] M. Hajli, "An intergrated model for $\mathrm{e}^{-}$-commerce 
addition at the customer level with the impact of social commerce," International Journal of Information Science and Management, vol. 16, no. Special Issue (ECDC 2012), pp. 77-97, 2012.

[27] D. Gefen, D. W. Straub, and M.-C. Boudreau, "Structural equation modeling and regression: Guidelines for research practice," Communications of the Association for Information Systems, vol. 4, no. 7, pp. 1-78, 2000.

[28] W. W. Chin, "Commentary: Issues and opinion on structural equation modeling," MIS Quarterly, vol. 22, no. 14, pp. vii-xvi, 1998.

[29] C. M. Ringle, S. Wende, and A. Will, "SmartPLS," 2005.

[30] W. W. Chin, A. Gopal, and W. D. Salisbury, "Advancing the theory of adaptive structuration: The development of a scale to measure faithfulness of appropriation," Information Systems Research, vol. 8, no. 4, pp. 342-367, 1997.

[31] B. H. Wixom, and H. J. Watson, "An empirical investigation of the factors affecting data warehousing success," MIS quarterly, vol. 25, no. 1, pp. 17-32, 2001.

[32] D. Gefen, and D. Straub, "A practical guide to factorial validity using PLS-Graph: Tutorial and annotated example," Communications of the Association for Information systems, vol. 16, 2005.

[33] P. Chwelos, I. Benbasat, and A. S. Dexter, "Research report: empirical test of an EDI adoption model," Information systems research, vol. 12, no. 3, pp. 304-321, 2001.

[34] H. van der Heijden, "User acceptance of hedonic information systems," MIS Quarterly, 28(4), pp. 695-704, 2004.

[35] H. Sun, and P. Zhang, "Causal Relationships between Perceived Enjoyment and Perceived Ease of Use: An Alternative Approach," Journal of the Association for Information Systems, vol. 7, no. 9, 2006.

[36] V. Venkatesh, "Creation of favorable user perceptions: Exploring the role of intrinsic motivation," MIS Quarterly, vol. 23, no. 2, pp. 239-260, 1999.

[37] R. Agarwal, and E. Karahanna, "Time flies when you're having fun: Cognitive absorption and beliefs about information technology usage," MIS Quarterly, vol. 24, no. 4, pp. 665-694, 2000.

[38] V. Venkatesh, "Determinants of perceived ease of use: Integrating control. intrinsic motivation, and emotion into the technology acceptance model," Information Systems Research, vol. 11, no. 4, pp. 342-365, 2000.

[39] V. Venkatesh, C. Speier, and M. G. Morris, "User acceptance enablers in individual decision making about technology: Toward an integrated model," Decision Sciences, vol. 33, no. 2, pp. 297-316, 2002.

[40] J. H. Schumann, F. V. Wangenheim, A. Stringfellow, Z. Yang, V. Blazevic, S. Praxmarer, G. Shainesh, M. Komor, R. M. Shannon, and F. R. Jiménez, "Cross-cultural differences in the effect of received word-of-mouth referral in relational service exchange," Journal of International Marketing, vol. 18, no. 3, pp. 62-80, 2010.

[41] J. W. Moon, and Y. C. Kim, "Extending the TAM for a world-wide-web context," Information and Management, 28(4), pp. 217-230, 2001.

[42] V. Venkatesh, and M. G. Morris, "Why don't men stop to ask for directions? gender, social influence, and their role in technology acceptance and usage behavior," MIS Quarterly, vol. 24, no. 1, pp. 115-139, 2000.

[43] J. Y. Thong, S. J. Hong, and K. Y. Tam, "The effects of post-adoption beliefs on the expectation-confirmation model for information technology continuance," International Journal of Human-Computer Studies, vol. 64, no. 9, pp. 790-810, 2006. 


\section{주지혁(Joo, Jihyuk)}

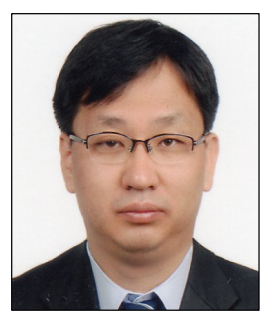

- 1998년 2월 : 한양대학교 신문방송 과(문학석사)

· 2003년 2월 : 한양대학교 신문방송 학과(문학박사, 언론학전공)

· 2003년 3월 현재 : 극동대학교 언론홍보학과 교수

· 2014년 7월 현재 : 노던아리조나 대학교 커뮤니케이션학부 방문학자

· 관심분야 : 뉴미디어, 수용자

·E-Mail : hyukjoo@kdu.ac.kr

\section{Appendix: Survey Items}

Note: The survey consisted of the following statements that were ranked on a five-point Likert scale: from "very strongly disagree(1)" to "very strongly agree(5)."

WOM (Schumann et al.[40] with some adaptation for the context)

WOM1. Friends of mine have told me positive things about social commerce.

WOM2. Friends of mine already have made good experiences with social commerce

WOM3. Friends of mine have recommended social commerce to me.

$P E$ (Moon \& Kim[41] with some adaptation for the context)

PE1. Using social commerce gives enjoyment to me.

PE2. Using social commerce stimulates my curiosity.

PE3. When interacting with social commerce, I do not realize the time elapsed.

PEOU (Davis[20]; Joo \& Sang[22] with some adaptation for the context)

PEOU1. Using social commerce is easy for me.

PEOU2. It would be easy for me to become skillful at using social commerce.

PEOU3. My interaction with social commerce is clear and understandable.
PU (Venkatesh \& Morris[42]; Thong, Hong \& Tam[43] with some adaptation for the context)

PU1. I find social commerce useful in my daily life.

PU2. Using social commerce helps me accomplish things more quickly.

PU3. Using social commerce increases my productivity.

PU4. Using social commerce helps me perform many things more conveniently.

PU5. Using social commerce enhances my effectiveness in my job

ITU (Agarwal \& Karahanna[37] with some adaptation for the context)

ITU1. I plan to use the Web in the future.

ITU2. I intend to continue using the Web in the future.

ITU3. I expect my use of the Web to continue in the future 